ORIGINAL ARTICLE

\title{
Safety of telephone consultation for "non-serious" emergency ambulance service patients
}

\author{
J Dale, S Williams, T Foster, J Higgins, H Snooks, R Crouch, C Hartley-Sharpe, E Glucksman, \\ S George
}

See end of article for authors' affiliations

Correspondence to: Professor J Dale, Centre for Primary Health Care Studies, University of Warwick, Coventry CV4 7AL, UK; jeremy.dale@ warwick.ac.uk

Accepted for publication 22 May 2004
Objective: To assess the safety of nurses and paramedics offering telephone assessment, triage, and advice as an alternative to immediate ambulance despatch for emergency ambulance service callers classified by lay call takers as presenting with "non-serious" problems (category C calls).

Design: Data for this study were collected as part of a pragmatic randomised controlled trial reported elsewhere. The intervention arm of the trial comprised nurse or paramedic telephone consultation using a computerised decision support system to assess, triage, and advise patients whose calls to the emergency ambulance service had been classified as "non-serious" by call takers applying standard priority despatch criteria. A multidisciplinary expert clinical panel reviewed data from ambulance service, accident and emergency department, hospital inpatient and general practice records, and call transcripts for patients triaged by nurses and paramedics into categories that indicated that despatch of an emergency ambulance was unnecessary. All cases for which one or more members of the panel rated that an emergency ambulance should have been despatched were re-reviewed by the entire panel for an assessment of the "life risk" that might have resulted.

Setting: Ambulance services in London and the West Midlands, UK.

Study population: Of 635 category $C$ patients assessed by nurses and paramedics, $330(52 \%)$ cases that had been triaged as not requiring an emergency ambulance were identified.

Main outcome measures: Assessment of safety of triage decisions.

Results: Sufficient data were available from the routine clinical records of 239 (72\%) subjects to allow review by the specialist panel. For 231 (96.7\%) sets of case notes reviewed, the majority of the panel concurred with the nurses' or paramedics' triage decision. Following secondary review of the records of the remaining eight patients, only two were rated by the majority as having required an emergency ambulance within 14 minutes. For neither of these did a majority of the panel consider that the patient would have been at "life risk" without an emergency ambulance being immediately despatched. However, the transcripts of these two calls indicated that the correct triage decision had been communicated to the patient, which suggests that the triage decision had been incorrectly entered into the decision support system.

Conclusions: Telephone advice may be a safe method of managing many category C callers to 999 ambulance services. A clinical trial of the full implementation of this intervention is needed, large enough to exclude the possibility of rare adverse events.
T he persistent growth in demand on emergency ambulance services is an international problem which has little to do with changing patterns of disease and injury but appears to reflect a range of societal and organisational factors. ${ }^{1}$ Between $11 \%$ and 52\% of emergency ambulance call outs are to patients with non-serious problems. ${ }^{1-15}$ Excessive demand may lead to delays in the arrival of ambulances to those with life threatening needs, potentially contributing to avoidable morbidity and mortality. ${ }^{16}$

There is limited evidence about the impact and acceptability of alternatives to immediate emergency ambulance despatch. ${ }^{1}$ It has been suggested that telephone assessment using computerised decision support could enable identification of whether alternatives to ambulance despatch could be safely offered. Telephone assessment systems have been piloted and evaluated in other contexts and have been shown to be acceptable to the public and to be safe. ${ }^{17}{ }^{18}$

We recently reported results from a pragmatic randomised controlled trial to assess the potential impact of telephone triage and advice to emergency ambulance callers-to our knowledge, the first study to test this intervention as an alternative to ambulance despatch. Of 635 emergency (999) ambulance service calls prioritised by call takers using priority despatch criteria as presenting with non-serious (category C) problems, approximately half $(52.0 \%)$ were triaged by nurses and paramedics using computerised clinical decision support as not requiring emergency ambulance despatch. ${ }^{19}$ The trial was conducted in shadow form-that is, with ambulances continuing to be despatched to all calls at the commencement of prioritisation by the call takerbecause of uncertainty about the safety of the intervention. Nurses were more likely than paramedics to triage calls as not requiring an ambulance, odds ratio 1.28 (95\% CI 1.12 to 1.47 ) after controlling for age, case mix, time of day, day of week, season, and ambulance service. Telephone assessment was found to be acceptable to callers. ${ }^{20}$

The main trial found that a significant proportion (almost $10 \%$ ) of patients triaged as not requiring immediate despatch of an emergency ambulance were subsequently admitted to inpatient hospital care, raising concerns about the safety of the intervention. ${ }^{19}$

The purpose of the study reported here is to re-analyse the trial data to assess the safety of the assessment and advice that had been provided in the light of health care needs identified in the days following the call to the emergency ambulance service. In-depth review of patients' records was 
Box 1 Description of population and methods included in the main trial

Study population: control and intervention groups The study population comprised all 999 (emergency ambulance) calls identified by call takers as presenting with category C (non-serious) problems during randomly sampled 4 hour sessions, with the exception of: children under the age of 2 years, hoax calls, alarm calls, and callers with comprehension/language difficulties that prevented assessment by the call taker.

Ambulances were despatched to all calls at the commencement of prioritisation, in accordance with the existing ambulance service procedure.

During the sampled sessions, $16 \%$ of emergency calls in London and $18 \%$ of those in the West Midlands were prioritised as category C. The management of these calls depended on whether the session was in the control or intervention group. During control sessions the calls received the usual ambulance response with no additional telephone assessment and advice. During intervention sessions, category $\mathrm{C}$ calls were passed to a nurse or paramedic, if available, for assessment, triage, and advice. After assessment of the presenting problem using a clinical decision support system, the caller was offered advice and, if appropriate, an opportunity to volunteer that an ambulance was no longer wanted. For the purpose of the study the nurse or paramedic recorded their triage assessment into one of five categories: (1) immediate care: emergency ambulance required; (2) urgent care: ambulance required; (3) moderately urgent: GP attention within 4-24 hours; (4) routine care such as routine GP appointment; or (5) home care advice.

\section{Nurses and paramedics}

Sixteen nurses and 10 paramedics participated in the study, all of whom were currently employed by NHS services in London and the West Midlands. The nurses were already experienced users of the clinical decision support system for out of hours or NHS Direct calls. Paramedics were recruited in London using the ambulance service's internal vacancy bulletin.

All participating staff attended an induction day that included an orientation to the study and training on a version of the decision support system that had been modified to support the needs of the study. In addition, the paramedics received in-depth training in the use of the system, followed by at least 14 hours' practice using role play scenarios. The skills and competencies of the nurses and paramedics were evaluated during a 90 minute session that involved simulated category $\mathrm{C}$ calls role played over the telephone with an actor. Nurses then completed a 4 hour "live" practice session while paramedics completed at least 8 hours of "live" practice sessions.

\section{Data collection methods}

Following each sampled session, data were collected on all category $\mathrm{C}$ calls from ambulance service records (patient name, contact address, age, ambulance attendance, ambulance arrival time) and from accident and emergency department records (diagnosis, treatment, investigations, and referrals). For patients assessed by a nurse or paramedic, the computerised call record provided information on the content of the nurse/paramedic telephone assessment including the questions and responses, length of assessment, patient's symptoms, advice given, and the nurse/paramedic assessment of need for an ambulance. Patients triaged using the decision support system as not requiring care within 4 hours (that is, "home care", "routine", or "moderately urgent" categories) were classified as not requiring an emergency ambulance, while those requiring an ambulance comprised those who needed "urgent" (within 2-4 hours) or "immediate" care (within 2 hours).

One week after the 999 call, all subjects (for children, the parent or guardian) were sent a questionnaire by post with a Freepost reply envelope. Patients in the intervention group received an additional Care Pathway questionnaire which asked subjects to report the care that they had received from community and hospital based services in the week subsequent to the call. If consent was given, GPs were contacted to provide information about any general practice care that had been provided in the week following the 999 call.

undertaken by an independent expert clinical panel to identify whether patients' lives may have been put at risk had their access to emergency care been delayed by the intervention.

\section{METHODS}

The recruitment of patients to the main trial, the intervention applied, and the data collection methods have been described elsewhere ${ }^{19}$ and are summarised in box 1. Data collection was conducted between April 1998 and May 1999. The trial was conducted across two ambulance service sites that together covered the whole of Greater London, Birmingham, Coventry, the Black Country, and South Staffordshire (a total population of approximately 10 million).

Nurses and paramedics trained in telephone assessment and advice worked within the ambulance service control rooms during randomly sampled 4 hour sessions between 07.00 and 23.00 hours across the entire data collection period. Emergency (999) calls were prioritised by control room call takers using a priority despatch system (box 2). Callers that were classed as category $\mathrm{C}$ were first reassured that the ambulance was on its way and then, during intervention sessions, transferred to a nurse or paramedic for further assessment and advice.

The subsample of patients assessed by nurses and paramedics as not requiring an emergency ambulance-that is, considered to require moderately urgent, routine care, or home care advice-were the subjects of the study reported here. The care pathway for each patient was defined from a variety of sources (box 1): follow up questionnaires posted to all patients 4-7 days after the call, ${ }^{20}$ ambulance service control room records and "at scene" records for patients attended by ambulance personnel, and episode records of all patients who attended accident and emergency departments or general practice within 4 days of the call.

\section{Assessment of safety of triage decisions: independent specialist review panel \\ Panel}

An independent specialist review panel was recruited to assess the clinical safety of the triage decision making. It was constituted to reflect clinical expertise at the interface between primary care and emergency care, and included a heterogeneous group as the aim of the study was to explore areas of uncertainty. To minimise institutional and professional bias, panellists were recruited from a variety of different organisational and institutional settings with nominations being sought from national professional bodies (Faculty of Accident and Emergency Medicine, Royal College of General Practitioners, Royal College of Nursing), and the London Ambulance Service. As a result, two accident and 


\section{Box 2 Emergency ambulance services in the UK}

In the UK there are 39 public sector ambulance services that together cover the entire population. They receive a total of over 5 million emergency calls each year, with demand increasing by about $5 \%$ per annum.

Emergency (999) calls from the public are automatically directed to the nearest emergency ambulance control room where details of the patient are taken and emergency ambulance services are dispatched. Call takers categorise the seriousness of the patient's illness or injury by asking a series of carefully structured questions into one of the following three levels: immediately life threatening; serious but not immediately life threatening; and neither immediately life threatening or serious. This system of priority dispatch means that, if there is a particularly high level of demand in one area and an ambulance is needed at two calls, it can be sent-or if necessary diverted-to the patient in the most serious condition.

Every 999 call is responded to by the nearest available ambulance. Other resources-such as paramedic motorcycles and cars - can also be sent to the most seriously ill or injured patients, while the Helicopter Emergency Medical Service (HEMS) is targeted at those with the most critical injuries. When help arrives, the patient's clinical condition will be assessed and treatment may be given at the scene. The patient is then either taken to the nearest hospital accident and emergency department or to a specialist facility such as a burns unit, with pre-hospital care being provided by the ambulance crew if needed.

emergency department consultants, two accident and emergency department nurses, two general practitioners, and two paramedics were recruited, with one of each being employed in London and the West Midlands. All worked in urban settings.

\section{Rating instrument}

At the first two meetings of the panel the nominal group technique ${ }^{21}$ was used, facilitated by EG, to develop and refine a set of questions for rating the safety and appropriateness of the telephone triage decision. The panel was instructed that "the classification of need for an emergency ambulance should be based on the patient's clinical condition as documented in ambulance, accident and emergency department or general practice records available for this episode". Following presentation of and discussion about the study's background, panellists were asked independently to develop and write down criteria that they would use for judging the appropriateness of the assessment and advice that had been provided by nurses and paramedics. These ideas were gathered systematically, followed by a group discussion to clarify them. Panellists then privately ranked each idea, the ranking was tabulated and presented, and the overall ranking was discussed and re-ranked. The final rankings were tabulated and used to develop an assessment schedule which was then discussed and approved by all members of the panel (Appendix 1).

The schedule was piloted on 10 cases and a high level of agreement was found between the panel's ratings for safety, with at least $75 \%$ of the panellists agreeing for seven cases. Panellists found that they were unable to judge the appropriateness of the triage decision for cases where accident and emergency department or GPs' notes were unavailable. For this reason, only cases with this information available were included in the main assessment process.
Assessment of cases

Of the 330 cases triaged in the main trial ${ }^{19}$ into categories indicating an absence of need for an emergency ambulance response, $239(72 \%)$ cases had sufficient data to meet the requirements of the review process. The remaining 91 (28\%) cases had either not attended an accident and emergency department or been in contact with a GP or, if they had attended, clinical records about this contact could not be retrieved.

Panellists were blind as to whether the call had been assessed by a nurse or a paramedic, and were unaware that they were only to receive cases where patients had been triaged as not requiring an emergency ambulance. For the purpose of confidentiality all cases were rendered anonymous.

The staticised group technique ${ }^{22}$ was used with panellists working independently using the agreed assessment schedule.

\section{Reliability}

After collation of the data from ratings made by panellists in their initial assessment of cases, a second review was undertaken to reassess all cases where one or more panellists indicated that they believed an emergency ambulance should have been despatched. Additional questions were included to clarify panellists' perceptions about the level of risk to the patient and the reason(s) for ambulance need. Intrarater reliability was tested on a further 10 randomly selected cases.

Panellists were unaware of the findings of the first round and, as in the first round, worked independently. In addition to the information made available on each case for the first review round, the panel was also provided with the call reports produced by the decision support system for each of these cases. This was to enable comparison of the information documented during the telephone assessment with the clinical findings documented subsequently, and so make an assessment of the reliability of the initial assessment.

\section{Statistical analysis}

For the purpose of analysis the patients triaged as not requiring an ambulance-that is, those triaged as either "moderate", "routine", or "home care advice"-were recoded into a single group. The analysis is based on the majority views of the panel (that is, at least five in agreement). The kappa statistic was used to test the reliability of majority views over the first and second assessment for cases rated as having required an emergency ambulance. Percentage agreements were calculated for intrarater reliability.

\section{Case studies}

The final stage of the review process involved analysis of transcripts of audiotaped recordings of any call for whom a majority of the panel (at either the first or second review) judged that an emergency ambulance should have been despatched to arrive within 14 minutes. This was to confirm whether or not mis-triage had occurred and to identify the extent to which these patients' needs had been identified during the telephone consultation.

The recordings were transcribed by ambulance service personnel and rendered anonymous. The transcripts were summarised by the researcher (SW) and the case transcripts and transcript summaries were sent to the chair of the review panel (EG) to confirm that the summaries were an accurate account of each call and to make an overall assessment of the safety of the triage decision.

\section{Ethical approval}

Ethical approval was granted by the multicentre regional ethics committee for South Thames and the 39 local research 
Table 1 Representativeness of the calls reviewed by the panel

\begin{tabular}{|c|c|c|c|}
\hline Variable & $\begin{array}{l}\text { Calls reviewed by } \\
\text { panel }(n=239)\end{array}$ & $\begin{array}{l}\text { Calls meeting inclusion } \\
\text { criteria but lacking } \\
\text { sufficient clinical data to allow } \\
\text { panel review ( } \mathrm{n}=91 \text { ) }\end{array}$ & $\chi^{2}$ test \\
\hline \multicolumn{4}{|l|}{ Age (years) } \\
\hline Mean, range (SD) & $40.5 ; 1-94(26.0)$ & $39.4 ; 1-92.5(28.7)$ & \multirow{4}{*}{$\begin{array}{l}\chi^{2}=1.90, p=0.3 \\
d f=2\end{array}$} \\
\hline $0-15$ years & $39(16.3 \%)$ & $20(22.0 \%)$ & \\
\hline $16-60$ years & 138 (57.7\%) & $48(52.7 \%)$ & \\
\hline $60+$ years & $62(25.9 \%)$ & $23(25.3 \%)$ & \\
\hline \multicolumn{4}{|l|}{ Sex } \\
\hline Males & $88(36.8 \%)$ & $26(28.6 \%)$ & \multirow{2}{*}{$\begin{array}{l}\chi^{2}=1.96, p=0.16 \\
d f=1\end{array}$} \\
\hline Females & 151 (63.2\%) & 65 (71.4\%) & \\
\hline \multicolumn{4}{|l|}{ Presenting problem } \\
\hline Neurological/head injury & $17(7.6 \%)$ & $6(8.0 \%)$ & \multirow{5}{*}{$\begin{array}{l}\chi^{2}=0.75, p=0.9 \\
d f=4\end{array}$} \\
\hline Falls/accidents & 72 (32.0\%) & 25 (33.3\%) & \\
\hline Sick/unknown & 73 (32.4\%) & $22(29.3 \%)$ & \\
\hline Back pain/abdominal pain & 46 (20.4\%) & 14 (18.7\%) & \\
\hline Other & $17(7.6 \%)$ & $8(10.7 \%)$ & \\
\hline \multicolumn{4}{|l|}{ Care received } \\
\hline Attended A\&E & $192(80.3 \%)$ & $12(14.0 \%)$ & \multirow{5}{*}{$\begin{array}{l}\chi^{2}=125 p<0.001 \\
d f=4\end{array}$} \\
\hline Assistance at scene & $23(9.6 \%)$ & $22(25.6 \%)$ & \\
\hline GP seen & $15(6.3 \%)$ & $30(25.6 \%)$ & \\
\hline Self-care & $7(2.9 \%)$ & $19(22 \%)$ & \\
\hline Other & $2(0.8 \%)$ & $3(3.5 \%)$ & \\
\hline
\end{tabular}

ethics committees responsible for the populations covered by the two ambulance services.

\section{RESULTS}

Table 1 indicates that there were no significant differences in age, sex, or presenting problems between the cases reviewed by the panel and those for whom insufficient data were available. However, there was a significant difference in the care pathway, with $192(80.3 \%)$ patients in the group sent to the panel having attended an accident and emergency department compared with only $12(14.0 \%)$ in the group for whom insufficient data were available to allow review by the panel.

\section{Review panel findings: initial assessment}

The initial assessment round achieved a $100 \%$ response rate from panellists. As shown in table 2, in 231 cases (96.7\%) the majority rated the patient as not needing an emergency ambulance.

There were 35 cases $(14.6 \%)$ for whom at least one member of the panel classified the patient as needing an ambulance within 14 minutes. Table 3 provides details of these cases. These included four (1.6\%) where a majority of the panel classified the patient as needing an emergency ambulance within 14 minutes (these cases are described in table 4), but for none of these was this view held unanimously. In

Table 2 Initial panel assessment: would the patient have come to harm (due to his/her clinical condition) if he/she did not receive an emergency ambulance within 14 minutes?

\begin{tabular}{lll}
\hline $\begin{array}{l}\text { Agreement between } \\
\text { panellists }\end{array}$ & $\begin{array}{l}\text { Patient would have } \\
\text { come to harm }(\mathbf{n})\end{array}$ & $\begin{array}{l}\text { Patient would not } \\
\text { have come to harm (n) }\end{array}$ \\
\hline 8 agree & 0 & 158 \\
7 agree & 0 & 39 \\
6 agree & 1 & 23 \\
5 agree & 3 & 11 \\
Total number of cases & 4 & 231 \\
with a majority view & & \\
(>4 panellists) & & \\
\hline
\end{tabular}

addition, there were four cases $(1.6 \%)$ without a majoritythat is, the panel was split 4:4 over the patient's need/absence of need for an ambulance within 14 minutes.

One member of the panel (an accident and emergency consultant) appeared to have a lower threshold for rating patients as needing an emergency ambulance and for 12 $(34.2 \%)$ of the 35 cases rated as needing an emergency ambulance he/she was the only panellist to state that this was necessary.

\section{Review panel findings: second assessment}

The panel were asked to re-review independently the 35 cases for whom at least one panellist had classified the patient as needing an ambulance within 14 minutes (table 3 ). The results of a cross tabulation revealed two cases (nos 1 and 2, table 4) who were reported at both assessment rounds by a majority of the panel as needing an emergency ambulance within 14 minutes.

There were 28 cases where the majority rated the patient as not requiring an emergency ambulance on reassessment and there was no majority view on the remaining five cases. This suggests good reliability from one assessment to the next $(\kappa=0.88, \mathrm{p}<0.0001)$, although the subsample of patients reassessed was not entirely representative of the full sample as they consisted of cases who had been identified by at least one panellist on the first assessment as being in need of an emergency ambulance.

The intrarater reliability results for the review panel on 10 randomly selected cases showed the following percentage agreement between the first and second assessments: (1) A\&E consultant, 60\%; (2) A\&E consultant 40\%; (3) GP, 100\%; (4) GP, 90\%; (5) paramedic, 90\%; (6) paramedic, 90\%; (7) A\&E nurse, 70\%; (8) A\&E nurse, 80\%. There were generally high levels of agreement between the two assessments for the majority of the panel, the exceptions being the two accident and emergency consultants.

\section{Level of risk}

For the 35 cases sent for re-review, panellists were asked to grade the level of risk to the patient's health had an emergency ambulance not been despatched. There were four cases where at least one panel member thought the patient would have been at "life risk" without an emergency 
Table 3 Investigations, primary diagnoses, treatment, and outcome from accident and emergency department notes of the 35 patients classified by at least one panellist as requiring an ambulance within 14 minutes

\begin{tabular}{|c|c|c|c|c|c|c|}
\hline $\begin{array}{l}\text { Case no } \\
\text { (sex, age) }\end{array}$ & Investigations & Primary diagnoses & Anatomical site & Treatment & Prescriptions & Outcome \\
\hline 1 (M, 69 years) & Bacteriology & CNS (exclude stroke) & N/A & IV fluids & IV Cefotaxime & Admission: Medicine \\
\hline 2 (F, 2 years) & Urine bacteriology & $\begin{array}{l}\text { UTI, CNS (exclude } \\
\text { stroke) }\end{array}$ & N/A & Not recorded & Not recorded & Admission: Paediatrics \\
\hline 3 (F, 83 years) & X-ray, urine test & Closed fracture & Hip & $\begin{array}{l}\text { IV fluids, parenteral } \\
\text { analgesia }\end{array}$ & Morphine & Admission: Orthopaedics \\
\hline 4 (F, 65 years) & $\begin{array}{l}\text { X-ray, ECG, } \\
\text { haematology, } \\
\text { biochemistry }\end{array}$ & Respiratory: COPD & N/A & $\begin{array}{l}\text { Other parenteral } \\
\text { drugs }\end{array}$ & $\begin{array}{l}\text { Doxapram, } \\
\text { salbutamol, frusemide, } \\
\text { ipratropium }\end{array}$ & Admission: Medicine \\
\hline 5 (F, 60 years) & $\begin{array}{l}\text { X-ray, ECG, } \\
\text { biochemistry }\end{array}$ & Urinary tract infection & N/A & Oral drugs & Trimethroprin & $\begin{array}{l}\text { Admission: Observation } \\
\text { ward }\end{array}$ \\
\hline 6 (F, 35 years) & $\begin{array}{l}\text { ECG, haematology, } \\
\text { cross-match, } \\
\text { biochemistry, urine }\end{array}$ & $\begin{array}{l}\text { Acute myocardial } \\
\text { infarction }\end{array}$ & N/A & $\begin{array}{l}\text { Observation, oral } \\
\text { analgesia }\end{array}$ & Buccal GTN & Admission: Medicine \\
\hline 7 (M, 84 years) & $\begin{array}{l}\text { X-ray, haematology, } \\
\text { cross-match, } \\
\text { biochemistry }\end{array}$ & Closed fracture & Hip & None recorded & Not recorded & Admission: Orthopaedics \\
\hline 8 (F, 93 years) & $\begin{array}{l}\text { X-ray, ECG, } \\
\text { haematology, } \\
\text { biochemistry, } \\
\text { bacteriology }\end{array}$ & Collapse ?cause & N/A & Observation & Not recorded & Admission: Orthopaedics \\
\hline 9 (F, 48 years) & $\begin{array}{l}\text { X-ray, haematology, } \\
\text { biochemistry }\end{array}$ & $\begin{array}{l}\text { Acute abdominal } \\
\text { pain }\end{array}$ & Abdomen & None recorded & Not recorded & Admission: Surgery \\
\hline 10 (F, 77 years) & $\begin{array}{l}\text { Biochemistry, } \\
\text { haematology }\end{array}$ & Local infection & Abdomen right & IV fluids & Other parenteral & Admission: Surgery \\
\hline 11 (F, 19 years) & $\begin{array}{l}\text { Biochemistry, } \\
\text { haematology, urine }\end{array}$ & $\begin{array}{l}\text { Gynaecological } \\
\text { conditions }\end{array}$ & Abdomen & None recorded & Not recorded & Admission: Gynaecology \\
\hline 12 (F, 83 years) & $\begin{array}{l}\text { X-ray, ECG, } \\
\text { haematology, } \\
\text { biochemistry, urine }\end{array}$ & $\begin{array}{l}\text { Cerebrovascular } \\
\text { condition }\end{array}$ & N/A & None recorded & Not recorded & Admission: Geriatric \\
\hline 13 (F, 55 years) & $\begin{array}{l}\text { X-ray, ECG, } \\
\text { haematology, cross- } \\
\text { match, urine }\end{array}$ & Collapse ?cause & N/A & IV fluids & Observation & Admission: Medicine \\
\hline 14 (M, 51 years) & $\begin{array}{l}\text { ECG, haematology, } \\
\text { biochemistry }\end{array}$ & Collapse ?cause & N/A & None recorded & Insulin & Admission: Medicine \\
\hline 15 (F, 48 years) & $\begin{array}{l}\text { Haematology, } \\
\text { biochemistry }\end{array}$ & $\begin{array}{l}\text { CNS conditions. } \\
\text { (exclude stroke) }\end{array}$ & N/A & Observation & Not recorded & Admission: Medicine \\
\hline 16 (M, 52 years) & $\begin{array}{l}\text { X-ray, ECG, } \\
\text { haematology, } \\
\text { biochemistry, urine, } \\
\text { bacteriology }\end{array}$ & $\begin{array}{l}\text { ? hepatitis, } \\
\text { ?pulmonary embolism }\end{array}$ & Abdomen & IV fluids & Not recorded & Admission: Medicine \\
\hline 17 (F, 86 years) & $\begin{array}{l}\text { X-ray, haematology, } \\
\text { biochemistry, urine, } \\
\text { bacteriology }\end{array}$ & UTI & N/A & $\begin{array}{l}\text { IV fluids, parenteral } \\
\text { drugs }\end{array}$ & Cefuroxine & Admission: Medicine \\
\hline 18 (F, 86 years) & $\begin{array}{l}\text { Haematology, } \\
\text { biochemistry }\end{array}$ & Nerve injury & Neck & None recorded & Not recorded & Admission: Orthopaedics \\
\hline 19 (M, 74 years) & None & $\begin{array}{l}\text { Other vascular } \\
\text { conditions. }\end{array}$ & $\begin{array}{l}\text { Lower leg } \\
\text { bilateral }\end{array}$ & Oral analgesia & Not recorded & Admission: Medicine \\
\hline 20 (F, 18 years) & $\begin{array}{l}\text { Haematology, cross- } \\
\text { match, biochemistry, } \\
\text { urine }\end{array}$ & $\begin{array}{l}\text { Gynaecological } \\
\text { conditions }\end{array}$ & Abdomen & IV fluids & Not recorded & Admission: Gynae \\
\hline 21 (M, 79 years) & $\begin{array}{l}\text { X-ray, ECG, } \\
\text { haematology, } \\
\text { biochemistry }\end{array}$ & $\begin{array}{l}\text { Cerebrovascular } \\
\text { conditions }\end{array}$ & N/A & Guidance: written & None & Discharge: Home \\
\hline 22 ( $M, 6$ years) & None & Allergy & N/A & None recorded & Not recorded & Discharge: Home \\
\hline 23 (M, 38 years) & $\begin{array}{l}\text { X-ray, ECG, } \\
\text { haematology, } \\
\text { biochemistry }\end{array}$ & $\begin{array}{l}\text { Respiratory conditions. } \\
\text { Other non-asthma }\end{array}$ & N/A & None recorded & $\begin{array}{l}\text { Amoxycillin, } \\
\text { paracetamol, } \\
\text { salbutamol inhaler }\end{array}$ & Discharge: GP \\
\hline 24 (M, 45 years) & $\begin{array}{l}\text { X-ray, ECG, } \\
\text { haematology, } \\
\text { biochemistry }\end{array}$ & $\begin{array}{l}\text { CNS conditions. } \\
\text { Other non-epilepsy } \\
\text { Alcoholic DTs }\end{array}$ & N/A & Oral drugs & $\begin{array}{l}\text { Vitamin B compound, } \\
\text { thiamine, diazepam }\end{array}$ & Discharge: GP \\
\hline 25 (F, 57 years) & None & Allergy & N/A & Parenteral drugs & Adrenaline & Discharge: self \\
\hline 26 (F, 80 years) & X-ray & Closed fracture & Foot left & Bandage & Codydramol & $\begin{array}{l}\text { Discharge: Home } \\
\text { Outpatients clinic }\end{array}$ \\
\hline 27 (F, 2 years) & None & Laceration & Face & $\begin{array}{l}\text { Steristrips, wound } \\
\text { glue }\end{array}$ & Not recorded & Discharge: Home \\
\hline 28 (F, 23 years) & Haematology & Allergy & N/A & $\begin{array}{l}\text { Oral drugs, } \\
\text { parenteral drugs }\end{array}$ & $\begin{array}{l}\text { Chlorpheniramine, } \\
\text { hydrocortisone }\end{array}$ & Discharge: Home \\
\hline 29 (F, 75 years) & None & Laceration & Head & $\begin{array}{l}\text { Sutures, wound glue, } \\
\text { tetanus booster }\end{array}$ & Not recorded & Discharge: GP \\
\hline 30 (F, 19 years) & Urine & Collapse ?cause & N/A & $\begin{array}{l}\text { Observation, } \\
\text { guidance (verbal) }\end{array}$ & Not recorded & Discharge: Home \\
\hline 31 (F, 32 years) & X-ray & Laceration, contusion & Lower leg left & $\begin{array}{l}\text { Dressing, wound } \\
\text { closure, Steristrips }\end{array}$ & Paracetamol & Discharge: GP \\
\hline 32 (F, 24 years) & $\begin{array}{l}\text { ECG, haematology, } \\
\text { biochemistry }\end{array}$ & $\begin{array}{l}\text { Gastrointestinal } \\
\text { Acute abdominal pain }\end{array}$ & Abdomen & Parenteral drugs & Codydramol & Discharge: GP \\
\hline 33 (M, 62 years) & Biochemistry urine & $\begin{array}{l}\text { CNS conditions } \\
\text { (exclude stroke), } \\
\text { ?epilepsy }\end{array}$ & N/A & $\begin{array}{l}\text { Observation, } \\
\text { guidance (verbal) }\end{array}$ & Not recorded & Discharge: GP \\
\hline
\end{tabular}


Table 3 Continued

\begin{tabular}{|c|c|c|c|c|c|c|}
\hline $\begin{array}{l}\text { Case no } \\
\text { (sex, age) }\end{array}$ & Investigations & Primary diagnoses & Anatomical site & Treatment & Prescriptions & Outcome \\
\hline 34 (F, 2 years) & $N / A$ & Swallowed coin & $N / A$ & Home care & N/A & $\begin{array}{l}\text { Parent reported patient } \\
\text { fine. No A\&E or GP } \\
\text { attendance occurred }\end{array}$ \\
\hline 35 (M, 19 years) & X-ray & Closed fracture & Ankle & $\begin{array}{l}\text { Bandage guidance } \\
\text { (verbal) }\end{array}$ & Codydramol & Discharge: Home \\
\hline
\end{tabular}

ambulance (patients nos 1, 2, 4 and 20; table 3), but none where a majority of the panel felt that a patient would have been at "life risk".

In table 5 the risk assessment results for the two cases for whom a majority of the panel felt an emergency ambulance should have been sent at both the initial and second review are presented. For neither case did the majority of the panel view that the patient's life would have been put at risk had an emergency ambulance not been despatched. Overall, the nurse and paramedic members of the panel rated patients as having potentially been placed at greater risk than did the medically qualified panel members.

\section{Case studies}

The final stage of the review process involved analysis of transcripts of the audiotaped recordings of the consultations of the four cases described in table 3. As the summaries show in Appendix 2, it appears that in case 1 the need for an urgent medical assessment of the patient (he had fallen) had been recognised in the consultation, but the advice had been given that the patient's GP might be best placed to do this in the first instance. Similarly, for case 4 the need for an urgent medical assessment was recognised (the patient had been unwell and deteriorating for several weeks), but again it was felt that this assessment should have been undertaken by a GP as he appeared to be stable at the time of the call to the emergency service.
The call transcripts showed that in neither of the remaining two cases was the caller advised that the emergency ambulance was not required. For case 3 the caller was specifically advised that hospital care was required and that he should not move until the ambulance crew arrived. It is therefore probable that, for cases 2 and 3, the triage decisions were incorrectly entered into the decision support system and the intended triage decision was that the patient needed urgent care.

\section{DISCUSSION}

The findings from this study support the view that telephone assessment, triage, and advice of non-urgent ambulance service callers may be a safe alternative to despatch of an emergency ambulance. An independent expert panel reviewed a range of data from the clinical records of 239 patients who had been assessed by nurses and paramedics using clinical decision support as not being in need of emergency ambulance despatch. The panel members, although blind to the decisions reached by the nurses and paramedics, showed a very high level of agreement with the decisions that had been reached and, for $96.7 \%$ of reviewed cases, the majority of members agreed with the view that emergency ambulance despatch was not needed. There were initially four cases $(1.6 \%)$ that were rated by a majority of members as needing an emergency ambulance, and a further four $(1.6 \%)$ where the panel was evenly split. However, on

Table 4 Details of the four cases classified by the panel majority as requiring an emergency ambulance within 14 minutes

\begin{tabular}{|c|c|c|c|c|}
\hline & Case 1 & Case 2 & Case 3 & Case 4 \\
\hline TAS advisor & Nurse 1 & Paramedic 1 & Paramedic 1 & Nurse 2 \\
\hline Caller & Carer & Relative & Patient & Relative \\
\hline Time of day & $12: 14$ & $07: 48$ & $06: 53$ & $10: 16$ \\
\hline Day of week & Friday & Wednesday & Friday & Sunday \\
\hline Priority despatch & $24 c 3$ & $17 c 3$ & $24 c 3$ & $17 c^{3}$ \\
\hline classification & Falls/accidents & Sick/unknown & Falls/accidents & Sick/unknown \\
\hline Sex & $M$ & $\mathrm{~F}$ & $\mathrm{~F}$ & $\mathrm{~F}$ \\
\hline Age (years) & 69 & 2 & 83 & 65 \\
\hline $\begin{array}{l}\text { Panel views on why ambulance } \\
\text { was needed }\end{array}$ & $\begin{array}{l}\text { Cerebral problem }(n=2) \\
\text { GCS } 11 / 15(n=2) \\
\text { Confusion and sepsis }(n=1) \\
\text { Primary neurological cause } \\
(n=1)\end{array}$ & $\begin{array}{l}\text { Convulsion in a } 2 \text { year } \\
\text { old }(n=4) \\
\text { High pyrexia }(n=1)\end{array}$ & $\begin{array}{l}\text { Fractured femur/pain } \\
\text { relief }(n=4)\end{array}$ & $\begin{array}{l}\text { Abnormal blood gases }(n=2) \\
\text { Oxygen levels low and patient } \\
\text { unresponsive }(n=2)\end{array}$ \\
\hline \multicolumn{5}{|l|}{$\begin{array}{l}\text { Diagnoses and treatment } \\
\text { (from A\&E notes) }\end{array}$} \\
\hline Investigations & Bacteriology & Urine bacteriology & X-ray, urine test & $\begin{array}{l}\text { X-ray, ECG, haematology, } \\
\text { biochemistry }\end{array}$ \\
\hline \multirow[t]{2}{*}{ Primary diagnoses } & $\begin{array}{l}\text { CNS (exclude stroke), other } \\
\text { non-epilepsy, ?meningitis } \\
\text { ?intracerebral bleed }\end{array}$ & $\begin{array}{l}\text { UTI, CNS (exclude stroke), } \\
\text { other non-epilepsy }\end{array}$ & Closed fracture & $\begin{array}{l}\text { Respiratory: Other non-asthma } \\
\text { Exacerbation COAD }\end{array}$ \\
\hline & N/A & $\mathrm{N} / \mathrm{A}$ & Hip & N/A \\
\hline Treatment & IV fluids & Not recorded & $\begin{array}{l}\text { IV fluids, parenteral } \\
\text { analgesia }\end{array}$ & Other parenteral drugs \\
\hline Prescriptions & Cefotaxime & Not recorded & Morphine & $\begin{array}{l}\text { Doxapram, salbutamol, } \\
\text { frusemide, ipratropium }\end{array}$ \\
\hline Outcome & Admission: Medicine & Admission: Paediatrics & Admission: Orthopaedics & Admission: Medicine \\
\hline
\end{tabular}


Table 5 Secondary panel assessment: if patient would have come to harm (due to his/her clinical condition) if he/she did not receive an emergency ambulance within 14 minutes, please grade the level of risk to the patient

\begin{tabular}{llll}
\hline Case & Life risk & $\begin{array}{l}\text { Short/long term } \\
\text { risk to health but } \\
\text { not to life }\end{array}$ & $\begin{array}{l}\text { No risk (i.e. patient } \\
\text { did not need an } \\
\text { immediate emergency } \\
\text { ambulance) }\end{array}$ \\
\hline 1 & $\begin{array}{l}4 \text { agree } \\
\text { (2 A\&E nurses, }\end{array}$ & $\begin{array}{l}2 \text { agree } \\
\text { (2 consultants) }\end{array}$ & $\begin{array}{l}2 \text { agree } \\
\text { (2 GPs) }\end{array}$ \\
2 & $\begin{array}{l}2 \text { paramedics) } \\
2 \text { agree } \\
\text { (one A\&E nurse, } \\
1 \text { paramedic) }\end{array}$ & $\begin{array}{l}3 \text { agree } \\
\text { (2 consultants, } \\
1 \text { A\&E nurse) }\end{array}$ & $\begin{array}{l}3 \text { agree } \\
\text { (2 GPs, 1 paramedic) }\end{array}$ \\
\hline
\end{tabular}

secondary review the number felt to need an emergency ambulance dropped to two cases $(0.8 \%)$, but there were no cases where a majority of the panel considered that the patient's life would have been at risk as a result of emergency ambulance despatch having been delayed as a result of the intervention. Analysis of transcripts revealed that for both of these cases it appeared that the triage decision had been incorrectly recorded-that is, from the transcript it was evident that the caller had been advised of the need for an emergency ambulance and that one was on its way. Hence, overall there was a very high level of agreement with the triage decisions made in the trial.

The review process revealed that it is often far from straightforward to decide from ambulance service, hospital, and general practice records whether or not an emergency ambulance is necessary. As in much of primary care, a clear diagnosis was often lacking. The purpose of telephone assessment of category $\mathrm{C}$ calls is to decide what response is likely to be in the patient's best interests, given the information that can be elicited about the patient's condition and knowledge about the services that are available. For example, an elderly person who falls from his/her chair would require assessment (face to face) and assistance back into the chair. It is questionable whether the immediate despatch of an emergency ambulance travelling with "lights

\section{Key messages}

- Faced with persistent growth in demand, alternatives to the traditional despatch of emergency ambulances are needed for patients who call with problems that are likely to be non-urgent.

- This study suggests that telephone triage and advice from nurses and paramedics using computerised clinical decision support may be a safe means of assessing the need for emergency ambulance despatch.

- This needs to be interpreted cautiously within the context of the services studied, the staff who participated, and the clinical decision support system used.

- In-depth review of clinical records by a multidisciplinary expert panel is a pragmatic means of assessing safety in a context in which the diagnosis is often unclear and objective outcome measures are lacking.

- Widespread adoption of this intervention is not recommended without further evidence of safety and efficacy. and sirens" and manned by a paramedic is warranted, but telephone advice alone in this situation is unlikely to be sufficient. On the other hand, a patient who has been unwell and deteriorating for several weeks (as in case 4, Appendix 2) might reasonably be considered to be best assessed by a GP familiar with their history unless their condition had clearly reached a point where emergency intervention was necessary, even though there is a likelihood that, following such assessment, they might be referred for admission.

The group of emergency ambulance callers who can best benefit from telephone advice needs to be more clearly defined through further evaluation and research. Priority despatch systems enable lay call takers to classify the urgency of patients' needs according to simple algorithms to ensure that those with the most urgent needs receive the swiftest response. They are designed to have high sensitivity for life threatening needs but tend to have low specificity; only a relatively small proportion of patients classified as category A tend to have life threatening needs. Just as there may be many category $\mathrm{C}$ calls for whom telephone advice is not suitable, there may be some calls assessed by call takers as being category B ("urgent") for whom telephone advice could offset the need for attendance by an emergency ambulance. The potential for refining priority despatch systems and for offering telephone assessment and advice to different types of callers should be explored.

In this study the clinical panel was only asked to consider the patient's clinical condition in their assessment of need for emergency ambulance attendance. In the real world, in addition to clinical indices, environmental and/or social circumstances influence the need for hospital admission. It is not clear from this study how these other factors might impinge on the triage decision making of nurses and paramedics in a live situation.

\section{Methodological limitations}

In interpreting these findings there are a number methodological limitations that need to be considered. As previously discussed, ${ }^{19}$ it was beyond the scope of this study to consider the extent to which the nurses and paramedics involved in the main trial were representative of their professional groups, or the extent to which outcomes were dependent on aspects of the computerised decision support system used. At the time of the study the decision support system was in wide use in the UK and had been the subject of published studies that had demonstrated its effectiveness and safety in out of hours care. ${ }^{18} 2324$

In terms of the clinical review process, 91 cases $(28 \%)$ were excluded because of a lack of information. This was because the patient had not attended an accident and emergency department or GP following the emergency ambulance callthat is, there was no clinical information available against which to judge the safety of the triage decision-or because clinical records could not be retrieved. There was no evidence to suggest that any of these cases had experienced serious adverse consequences, but this could not be ruled out.

The validity of the clinical information available to the panel also needs to be considered. The data were derived from a variety of sources to provide an overview of the clinical needs of each patient at the time that the emergency ambulance service was called. In addition to patients' clinical needs, such records are likely to reflect a variety of other factors including the experience and grade of the consulting clinician. For example, junior medical staff in accident and emergency departments tend to over-investigate, treat, and refer for admission. ${ }^{25}$

The panel was composed of people who were expert in the appropriate area, were suggested for their experience and interest by professional organisations, had local knowledge of 
the health services being studied, and were likely to have credibility with their peers. ${ }^{26-28}$ The extent to which differences in panellists' views reflected professional or other factors could not be judged, although there was some evidence of variation according to professional group in the ways that risk were assessed, with the GP members of the panel being the least risk averse. The differences in views between individual professionals, between professional groups, and between individuals over time are in themselves interesting and reflect the difficulty of working in an area like this without an agreed gold standard. It is possible that the results would have differed if the panel had consisted of members from only a single specialty, or simply different panellists. ${ }^{29}$ As the purpose of the study was to identify whether the intervention was safe enough to be recommended for full implementation in a live trial, we felt justified to focus on the majority view rather than on the views of individual panellists.

In conclusion, the results from this study suggest that the provision of computer assisted telephone assessment and advice within the context of a trial may be a safe method of responding to category $\mathrm{C}$ emergency ambulance service calls. There was no evidence that safety had been seriously compromised. However, the disagreement observed between panellists about the need for attendance of an emergency ambulance leaves some uncertainty about the definitiveness of the conclusions of this study. Furthermore, the possibility of rare adverse events cannot be discounted, particularly given the extent to which there were missing data. The findings need to be interpreted within the context of the setting, the method of training of the paramedics and nurses, and the particular decision support software. It is now national policy that NHS Direct, the national nurse led telephone advice service, will in future triage emergency calls that are prioritised as being of a non-urgent nature. ${ }^{30} \mathrm{We}$ consider that widespread adoption will be premature without further evaluation of safety. The findings reported here provide sufficient evidence of safety to support undertaking a full trial.

\section{ACKNOWLEDGEMENTS}

The authors are grateful to Andy Cook, Dr Paul Davis, Peter Dowd, Dr Katherine Henderson, Lynda Holt, Sarah Horne, Dr Ellen Jones, and Dr George Paige for their involvement in the review process, and to the staff in the accident and emergency departments, ambulance services, and general practices who supported data collection.

\section{Authors' affiliations}

J Dale, J Higgins, Centre for Primary Health Care Studies, Warwick Medical School, University of Warwick, Coventry, UK

S Williams, Department of General Practice \& Primary Care, Guy's, King's and St Thomas' School of Medicine, London, UK

T Foster, C Hartley-Sharpe, London Ambulance Service NHS Trust, London, UK

H Snooks, Centre for Health Improvement Research and Evaluation (CHIRAL), Clinical School, University of Wales Swansea, Swansea, UK R Crouch, School of Nursing \& Midwifery, University of Southampton, Southampton, UK

E Glucksman, King's College Hospital NHS Trust, London, UK S George, Health Care Research Unit, University of Southampton

Funding: The study was funded by the NHSE R\&D Primary Secondary Interface Programme.

Competing interests: JD and RC have a financial interest in and act as clinical consultants to the Plain Software Company.

Contributors: All the authors were part of the project team. JD, HS, RC and Kathy Jones initiated the study, and with SW, EG and SG drafted the grant application and designed the study protocol. SW, TF, and JH were responsible for the development and piloting of data collection tools, the recruitment of patients and nurses, and for the collection, coding and analysis of all data. HS, CHS and trainers at the London
Ambulance Service recruited and trained the paramedics. The Plain Software Company trained nurses and paramedics in the use of the decision support system. SW designed and managed the review process and EG chaired the review panel. JD and SW wrote the paper and all authors contributed to its drafting and the interpretation of findings. SW, TF and JH are guarantors of the data.

\section{REFERENCES}

1 Snooks H, Williams S, Crouch R, et al. NHS emergency response to 999 calls: alternatives for cases that are neither life-threatening nor serious. BMJ 2002;325:330-3.

2 Richards JR, Ferrall SJ. Inappropriate use of emergency medical services transport: comparison of provider and patient perspectives. Acad Emerg Med 1999;6:14-20.

3 Palazzo FF, Warner OJ, Harron M, et al. Misuse of the London ambulance service: how much and why? J Accid Emerg Med 1998;15:368-70.

4 Little GF, Barton D. Inappropriate use of the ambulance service. Eur J Emerg Med 1998;5:307-1 1

5 Holm O, Berlac PA, Jensen PK, et al. Relevance of the 112-emergency calls among the clientele of the emergency department of the Herlev hospital admitting office. Ugeskr Laeger 1997;159:1749-51.

6 Chen JC, Bullard MJ, Liaw SJ. Ambulance use, misuse, and unmet needs in a developing emergency medical services system. Eur J Emerg Med 1996;3:73-8

7 Billitier A, Moscati R, Janicke D, et al. A multi-site survey of factors contributing to medically unnecessary ambulance transports. Acad Emerg Med 1996;3:1046-52.

8 Brown E, Sindelar J. The emergent problem of ambulance misuse. Ann Emerg Med 1993;22:646-9.

9 Pennycook AG, Makeower RM, Morrison WG. Use of the emergency ambulance service to an inner city accident and emergency department - a comparison of general practitioner and '999' calls. J R Soc Med 1991;84:726-7.

10 Gardner GJ. The use and abuse of the emergency ambulance service: some of the factors affecting the decision whether to call an emergency ambulance. Arch Emerg Med 1990;7:81-9.

11 Kongelf E, Lereim I, Hald K. Requests for ambulances for patients with acute diseases and injuries. Are ambulance services abused? Tidsskr Nor Laegeforen 1989; 109:3447-51.

12 O'Leary C, Bury G, McCabe M, et al. Ambulance-user analysis in an accident and emergency department. Ir Med J 1987;80:422-3.

13 Rademaker AW, Powell DG, Read JH. Inappropriate use and unmet need in paramedic and non-paramedic ambulance systems. Ann Emerg Med 1987; 16:553-6.

14 Morris DL, Cross AB. Is the emergency ambulance service abused? BMJ 1980;3:121-3.

15 Gibson G. Measures of emergency ambulance effectiveness: unmet need and inappropriate use. J Am Coll Emergy Phys 1977;6:389-92.

16 Audit Commission. A life in the fast lane: value for money in emergency ambulance services. Belmont Press, 1998.

17 O'Cathain A, Munro JF, Nicholl JP, et al. How helpful is NHS Direct? Postal survey of callers. BMJ 2000;320:1035.

18 Lattimer V, George S, Thompson F, et al. Safety and effectiveness of nurse telephone consultation in out of hours primary care: randomised controlled trial. BMJ 1998;317:1054-9.

19 Dale J, Higgins J, Williams S, et al. Computer-assisted assessment and advice for 'non-serious' 999 ambulance service callers: the potential impact on ambulance despatch. Emerg Med J 2003;20:178-83.

20 LASTAP Final Report. The clinical, organisational and cost consequences of computer-assisted telephone advice to category C 999 ambulance service callers: results of a controlled trial. University of Warwick. Available at: http://www.warwick.ac.uk/primary_care/ASTAP-final report.pdf.

21 Delbecq A, Van de Ven A. A group process model for problem identification and program planning. J Appl Behav Sci 1971;7:467-92.

22 Murphy MK, Black NA, Lamping DL, et al. Consensus development methods and their use in clinical guideline development. Health Technol Assess 1998;2(3).

23 Lattimer V, Sassi F, George S, et al. Cost analysis of nurse telephone consultation in out of hours primary care: evidence from a randomised controlled trial. BMJ 2000;320:1053-7.

24 Thompson F, George S, Lattimer V, et al. Overnight calls in primary care: randomised controlled trial of management using nurse telephone consultation. BMJ 1999;319:1408.

25 Dale J, Green J, Reid F, et al. Primary care in the accident and emergency department: II. comparison of general practitioners and hospital doctors. BMJ 1995;311:427-30.

26 Fink A, Kosecoff J, Chassin M, et al. Consensus methods: characteristics and guidelines for use. Am J Publ Health 1984;74:979-83.

27 Jones J, Hunter D. Consensus methods for medical and health services research. BMJ 1995;311:377-80.

28 Lomas J. Words without action? The production, dissemination and impact of consensus recommendations. Ann Rev Publ Health 1991;12:41-65.

29 Scott EA, Black N. When does consensus exist in expert panels? J Publ Health Med 1991;13:35-9.

30 Department of Health. Reforming emergency care. London: Department of Health, 2001 


\section{ASSESSMENT OF PATIENT'S NEED FOR AN AMBULANCE}

\section{PATIENT CASE NO:}

\section{REVIEWER ID:}

Please complete the following questions on each case according to your own assessment of the patient's need for an ambulance and / or treatment in $A \& E$, after carefully reading through all the information on the case. The classification should be based on the patient's actual clinical condition as shown during transit (patient report form) or as diagnosed in the clinical A\&E or GP notes. Alternatively, use your own judgement based on information provided on the Patient Report Form (ambulance crew information) and Patient Care Record Form (questionnaire completed by the patient following the 999 call), when there is no available A\&E or GP clinical information.

\section{Please tick your responses}

1.a Would the patient have come to harm (due to his/her clinical condition) if he/she did not receive an emergency ambulance within 14 minutes?

Yes

No (go to question 2)

\section{Unsure (go to question 2)}

Insufficient information (go to question 2)

1.b If yes to question 1, please grade the level of risk to the patient:

Life risk

Short/long-term risk to health but not life $\square$ Little risk

Insufficient information

1.c Please write the reason/s why:

2. If no or unsure to question 1 (i.e. the patient did not require an emergency ambulance within 14 minutes) where is the most appropriate place for this patient to have been treated:

Hospital (go to question 3)

Community facilities (go to question 3)

Home (go to question 3)
Unsure (go to question 3)

Insufficient information (go to question 3)

3. If no or unsure to question 1 (i.e. the patient did not require an emergency ambulance within 14 minutes) then please rate how soon this patient needed medical attention:

\section{Same day (go to question 4)}

Next day (go to question 4)

Next available appointment (go to question 4)

\section{Unsure (go to question 4)}

Insufficient information (go to question 4)

4. If no or unsure to question 1, please write which alternative response would have been more appropriate than sending an ambulance (e.g. assessment by a paramedic at the scene, GP or district nurse to visit, patient uses own transport/taxi to A\&E, hospital transport vehicle, MIU, other telephone advice such as NHS Direct) 


\section{APPENDIX 2: AUDIOTAPED RECORDINGS OF THE CONSULTATIONS OF THE FOUR CASES DESCRIBED IN TABLE 4}

\section{CASE 1 (69 YEAR OLD MAN LIVING IN RESIDENTIAL HOME WHO HAD FALLEN) \\ Caller}

The caller was a district nurse who was visiting the patient. She did not want to move the patient until help arrived and did not have anyone to assist her. She had not spoken to the patient's GP prior to calling the ambulance service.

\section{Presenting problem}

The patient had been found on the floor of a residential home and was conscious but not responding verbally. There were no apparent injuries. He was not having difficulty breathing. The district nurse thought that he had mobility problems and had previously suffered a stroke.

\section{Assessment and advice}

On receiving the call from the call taker the advisor first reassured the caller: "Hello it's [name], the nurse. The ambulance is on the way." The nurse established the age of the patient and contact details and carried out telephone assessment.

After completing assessment of the patient, the nurse suggested the caller might contact a colleague (another district nurse) to attend to help lift the patient into a chair. The caller stated that this was not possible because of nurses being off sick, and the nurse again reassured the caller that the ambulance was on its way.

The nurse went on to suggest that it would have been more appropriate to have contacted the GP, and asked "..have you spoken to his doctor?....morning surgery would have finished and I'm sure the doctors will be off doing their visits and one can come round and examine him." The caller stated that she did not know whether they would attend. The nurse suggested that it was not really appropriate in the first instance for an emergency ambulance, but again reassured the caller that "there is an ambulance on the way, so the team will be there shortly and they will certainly be able to help you."

The nurse also asked if there was any lifting equipment in the house. The caller explained that there was no equipment. The nurse asked about neighbours and the caller explained that they were all elderly. The nurse responded by reassuring the caller: "Right $O K$, and you can't get him up. Well I think really then that this was the only option wasn't it, to call someone for help? But you'll probably find when the ambulance arrives that they'll suggest you call the GP." The nurse stated that the patient needed to see a doctor but that it would probably be better if he saw his own GP. The caller said that she would call the doctor.

Total word count of call: advisor $=499$, caller $=381$.

\section{CASE 2 (2 YEAR OLD CHILD WITH A HIGH FEVER) Caller}

The caller was the mother of the child. Before calling the ambulance service the mother had contacted the GP and since the GP could not attend immediately, the doctor told her to call for an ambulance.

\section{Presenting problem}

The child's temperature was high and, according to the mother, she had just started shivering and shaking, but not fitting. Her eyes were not rolling and her breathing was fine. She had a stomach ache and a headache. The child was also crying. She did not have cold symptoms. At the time of the call the child could not keep Calpol (paracetamol) down, but was not vomiting. The child was thirsty and drinking frequently. Her bowel movements were normal. The patient had not been taken abroad recently and had no history of convulsions. The stomach ache had started 5 days previously and the child had been seen by a doctor then and had been diagnosed as having a viral gastric condition. There had been no prescription of antibiotics given. The child had also been seen by the GP at 18.00 hours the previous evening with the stomach ache and a temperature of 104. A urine sample had been taken. The mother had been able to control the child's temperature through the evening with Calpol.

\section{Assessment and advice}

On receiving the call from the call taker the advisor said "Hello there, paramedic here." The mother explained that she had been told by the GP to call for an ambulance. After taking additional history, the paramedic reassured the mother that the ambulance was on the way: "... there's an ambulance on its way, we're not delaying the ambulance, don't worry". The paramedic through the course of the assessment reassured the caller at times and repeated that there was an ambulance on its way.

Whilst carrying out the assessment the paramedic provided home care advice and information on regulating the child's temperature (e.g."Kids ... are not brilliant at controlling their own body temperature...so we need to, don't overheat her but don't overcool her, you just need to make sure she's OK and not too hot but not too cool OK ... is she dressed? "She's got her pyjamas on, that's fine, alright well don't warm her up any more than that OK.").

Total word count of call: advisor $=1082$, caller $=491$.

\section{CASE 3 (83 YEAR OLD WOMAN WHO HAD FALLEN)} Caller

The caller was the patient who was alone at home at the time of the call.

\section{Presenting problem}

She had fallen in the hallway of the house after passing out within the previous 2 hours. The patient was on her way to the toilet and had urinated on herself after the fall. She was unable to get up or move and had great pain high up in her right leg but could move her toes. There was no bleeding and no injury to her head. The patient was dressed only in night clothes, the heating was turned off, and she was very cold. She did not have a history of falls and had no difficulty breathing.

\section{Assessment and advice}

The advisor explains that the caller was speaking with a paramedic. The paramedic explained that there would be no delay in the ambulance arrival and through the course of the call further reassurance was given to the patient that the ambulance was on the way.

The paramedic advised the patient not to move her leg. The paramedic explained "We'll wait for the ambulance to get there and pick you up. We'll let them assess you properly.to make sure you've not hurt your leg ...". The paramedic further explained "... the ambulance crew will have a look at you and sort you out ... and they'll probably pop you into hospital." The paramedic asked if she could open the door and said if there was any difficulty to let the ambulance service know and they would find another way of getting into the house. The paramedic also asked many questions unrelated to making a decision on the need for an ambulance.

Total word count of call: advisor $=662$, caller $=335$. 


\section{CASE 4 (65 YEAR OLD WOMAN WHO HAD BEEN SHOWING INCREASING SELF-NEGLECT OVER PREVIOUS WEEK) \\ Caller}

The caller was the daughter of the patient and was visiting the mother's house at the time of the call. The patient lived alone. The caller had been going to call the GP 2 days earlier but the patient requested her not to call the doctor. The patient had not wanted her daughter to call for an ambulance.

\section{Presenting problem}

The patient had reportedly not eaten over the previous 2 weeks and appeared to be neglecting herself. She could speak but was unresponsive and moribund. The patient had been deteriorating over the past 4 weeks but particularly over the previous week. She was lethargic and had only been drinking cold drinks. She appeared to have lost weight and was weak. The patient had been depressed since moving house nearly 2 years previously. She had not seen a doctor or been out of the house for over a year. The daughter did everything for her mother. The patient was not on medication and had not been suicidal or shown signs of self-neglect in the past.

\section{Assessment and advice}

The advisor said to the caller "It's OK, you're through to a nurse". The advisor suggested that the patient may suffer from agoraphobia and explained: "it's a condition where people don't want to go outside". The caller agreed with this. The nurse also suggested the patient may be depressed and the daughter confirmed this and reported that she was also herself suffering from depression for which she was on medication. The nurse suggested that the patient may have "just lost interest in everything" as a result of depression.

The nurse explained that the patient needed to see her own GP who could provide nourishing fortified drinks to build up the patient's strength. She suggested that, if the patient was taken to A\&E by ambulance, she could be waiting a long time to be seen and this might be off-putting to the patient. She suggested that the caller should take the patient to the GP in future. The advisor instructed the caller to contact the patient's own GP the next day.

Total word count of call: advisor $=419$, caller $=751$.

\section{Clinical Evidence-Call for contributors}

Clinical Evidence is a regularly updated evidence based journal available worldwide both as a paper version and on the internet. Clinical Evidence needs to recruit a number of new contributors. Contributors are health care professionals or epidemiologists with experience in evidence based medicine and the ability to write in a concise and structured way.

\section{Currently, we are interested in finding contributors with an interest in} the following clinical areas:

Altitude sickness; Autism; Basal cell carcinoma; Breast feeding; Carbon monoxide poisoning; Cervical cancer; Cystic fibrosis; Ectopic pregnancy; Grief/bereavement; Halitosis; Hodgkins disease; Infectious mononucleosis (glandular fever); Kidney stones; Malignant melanoma (metastatic); Mesothelioma; Myeloma; Ovarian cyst; Pancreatitis (acute); Pancreatitis (chronic); Polymyalgia rheumatica; Post-partum haemorrhage; Pulmonary embolism; Recurrent miscarriage; Repetitive strain injury; Scoliosis; Seasonal affective disorder; Squint; Systemic lupus erythematosus; Testicular cancer; Varicocele; Viral meningitis; Vitiligo However, we are always looking for others, so do not let this list discourage you.

\section{Being a contributor involves:}

- Appraising the results of literature searches (performed by our Information Specialists) to identify high quality evidence for inclusion in the journal.

- Writing to a highly structured template (about 2000-3000 words), using evidence from selected studies, within 6-8 weeks of receiving the literature search results.

- Working with Clinical Evidence Editors to ensure that the text meets rigorous epidemiological and style standards.

- Updating the text every eight months to incorporate new evidence.

- Expanding the topic to include new questions once every 12-18 months.

If you would like to become a contributor for Clinical Evidence or require more information about what this involves please send your contact details and a copy of your CV, clearly stating the clinical area you are interested in, to Claire Folkes (cfolkes@bmigroup.com).

\section{Call for peer reviewers}

Clinical Evidence also needs to recruit a number of new peer reviewers specifically with an interest in the clinical areas stated above, and also others related to general practice. Peer reviewers are health care professionals or epidemiologists with experience in evidence based medicine. As a peer reviewer you would be asked for your views on the clinical relevance, validity, and accessibility of specific topics within the journal, and their usefulness to the intended audience (international generalists and health care professionals, possibly with limited statistical knowledge). Topics are usually 2000-3000 words in length and we would ask you to review between 2-5 topics per year. The peer review process takes place throughout the year, and our turnaround time for each review is ideally 10-14 days.

If you are interested in becoming a peer reviewer for Clinical Evidence, please complete the peer review questionnaire at www. clinicalevidence.com or contact Claire Folkes(cfolkes@bmjgroup.com). 